\title{
Heat Transfer and Flow Characteristic of Two-phase Flow in a Rotational Narrow Annular Channel
}

学 ○鉿木 貴也（関大院） 正 梅川 尚嗣（関大工） 正 小澤 守（関大工）

Takaya SUZUKI, Hisashi UMEKAWA, Mamoru OZAWA, Kansai University, 3-3-35, Yamate-cho, Suita, Osaka

\section{1 緒 言}

回転同心二重円筒内の研究では，Taylor 渦に関するもの が有名であるが，主として単相流を対象としていた．しか し近年では液体燃料のターボポンプや気液分離装置,さら には反応器への応用等にも関連して単相流のみではなく気 液二相流をも対象として研究が行われている，本研究はせ ん断力が強く作用する場での気液二相流の伝熱おるび流動 特性を実験的に評価した，本報では，既報(1)と同様の実呀 装置を用い差圧特性および伝熱特性の測定を行ったのでこ こに報告する.

\section{2 実験装置および実娩方法}

空気 - 水系で使用した装置は既報 ${ }^{(1)}$ と同様の装置で, 内 径 $41.5 \mathrm{~mm}$ のアクリル樹脂製円筒と外径 $40 \mathrm{~mm}$ の真鍮製回 転軸で形成される $0.75 \mathrm{~mm}$ の環状流路を有するものである. 実験条件は気相流束 $\mathrm{J}_{\mathrm{G}}=0.0196-4.965 \mathrm{~m} / \mathrm{s}$, 液相流束 $\mathrm{J}_{\mathrm{L}}=0.0148-0.216 \mathrm{~m} / \mathrm{s}$, 内軸回転数 $0-3000 \mathrm{rpm}$ の範囲である. これらの值から液相テイラー数を求めると $\mathrm{Ta}_{\mathrm{L}}=0-7.746 \times$ $10^{5}$ となる。なお，本装置の臨界テイラ一数は 1763 であり テイラー渦が生じる臨界回転数は $140 \mathrm{rpm}$ に相当し, この 回転数付近でテイラー渦が形成されていることを確認して いる.

加熱系で使用した実験装置の概略図を Fig.1 に示す. 作 動流体として液体空素を用いた沸滕系ループであり，テス トセクションは内径 $42 \mathrm{~mm}$ の銅製円筒と外径 $40 \mathrm{~mm}$ のステ ンレス製回転軸で形成される $1.0 \mathrm{~mm}$ の環状流路を有して いる. 加熱長さは 309mm であり銅製外筒の周りにロウ付 けしたシースヒータにより加熱を行っている，(1液体窒素 ボンベから圧送された液体窒素は(2)へッドコラムを経由し (3)サブクーラーで系内外圧の飽和温度差によりサブクール 度を確保した後(4)テストセクションへと流入する。この時 の流量注(6)蒸発器により完全に気化させた状態で(7)オリフ イスを用いて測定を行った. 加熱系での実験条件は系圧 $0.4 \mathrm{MPa}$ ，質量流束 $\mathrm{G}=20 \mathrm{~kg} / \mathrm{m}^{2} \mathrm{~s}$ ，加熱熱流束 $\mathrm{q}=0-25 \mathrm{~kW} / \mathrm{m}^{2}$, 内軸回転数 0-800rpm である.

なお, 本装置は十 分な断熱を行ってい るが低温流体である ため熱侵入は避けら れず，非加熱時の工 ンタルピー増加から 推算しておよそ $1-2 \mathrm{~kW} / \mathrm{m}^{2}$ が入熱し ているものとして評 価している。

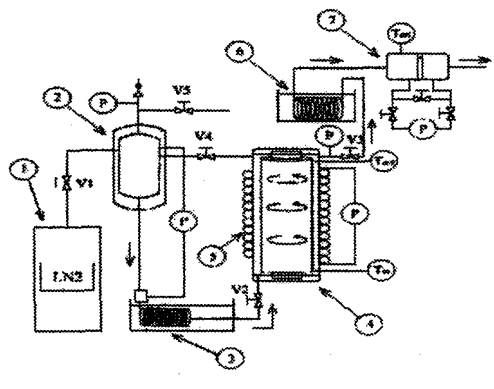

Fig.1 Experimental apparatus

\section{3 実倹結果および考察}

Fig.2 は空気 - 水系実験で得られた摩摖項の值である. 図 中には軸流を伴う回転軸系での単相流に対して求めた浅沼 (2)ならびに山田 ${ }^{(3)}$ の計算式をべースとして二相流モデルと して均質流ならびに L-M モデルを用いた值を併記してい る.このような系では回転が加わることで摩擦項は増加す るが，この図で見られるように浅沼，山田の式で回転数の 増加による差圧の増加をうまく表現できることがわかる. また本実験範囲に対しては浅沼の式に均質流モデルを適用 した値の方が若干相関は高かった。

加熱系で得られた差圧測定結果を Fig.3 に示す. 図中に は浅沼の式に均質流モデルおよび L-M モデルを用いた值 を併記している．図は加熱熱流束一定の条件下で回転数を 変化させて得られた結果であり, 空気一水系での結果同様 回転数の増加とともに若干差圧は増加し, 浅沼の式に均質 流モデルを適用した結果とよく一致していることがわか る.

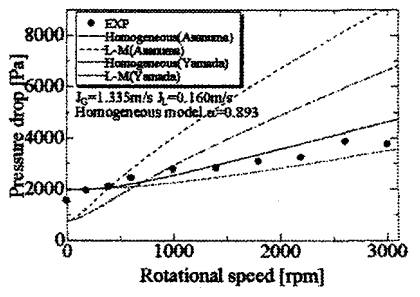

Fig.2 Estimation of the friction term (air-Water)

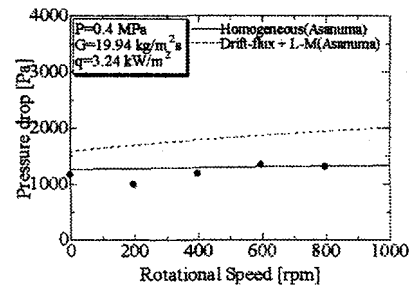

Fig.3 Estimation of Pressure Difference (Boiling)
次に Fig.4に静止時と回転時の限界熱流束の比について 示す. 回転数の増加に従い，限界熱流束時の加熱熱流束は 増加し，800rpmにおいては軸静止時状態のおよそ 1.2 倍の 加熱熱流束であることがわかった.これは作動流体に遠心 力が作用し，液相が環状流路外側に移動することなどから 内部の流動構造が変化し，限界熱流束の増加につながった ものと考えられる。

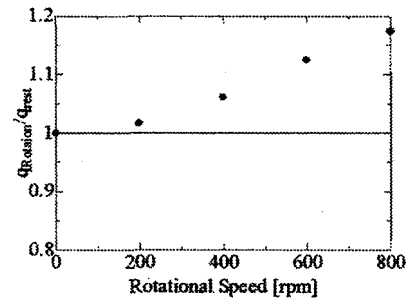

Fig.4 Relationship between $\mathrm{CHF}$ and rotational speed 4 参考文献

(1)羽田野他，日本混相流学会年会公演論文集(2004)，13

(2)浅沼，機論，17-60(1951) 140

(3)山田, 機論, 27-180(1961) 1267 